\title{
Agricultural impacts on Mediterranean wetlands : the effect of pesticides on survival and hatching rates in copepods
}

\author{
G. Parra, R. Jiménez-Melero, F. Guerrero*
}

Departamento de Biología Animal, Biología Vegetal y Ecología, Campus de las Lagunillas s/n. E-23071 Jaén, Spain.

\begin{abstract}
Wetlands are one of the most altered natural systems due to the creation and development of agricultural landscapes. Some of agriculture's impacts are in relation to water quality decreases, due to the use of potentially toxic herbicides or pesticides, and they are responsible of ecological alterations. This study shows the negative effect that two pesticides generate in a population of the copepod Arctodiaptomus salinus in an aquatic ecosystem that is surrounded by intensive olive tree cultivation. Adult females and egg sacs of that calanoid copepod were exposed to different concentrations of copper sulphate and the pesticide dimethoate, to examine their tolerance response. The adult lethal concentration obtained was lower than the regular dose of pesticide used in olive agriculture. These results also reflect the negative effect over A. salinus secondary production as a consequence of the increase in females and nauplii mortality and by the hatching rate reduction.
\end{abstract}

Keywords : Arctodiaptomus salinus, copper, dimethoate, Mediterranean wetlands, secondary production.

\section{Introduction}

Mediterranean wetlands are ecological systems with a broad variety of natural resources with environmental, social and scientific values (Bernáldez 1987). In Spain, as in many Mediterranean areas, these wetland ecosystems have been subjected to a strong human influence, being that wetlands are one of the most altered natural systems by the creation and development of converging agricultural landscapes (Casado \& Montes 1995). The regular procedures in agriculture generate unquestionable environmental impacts, because agricultural practices produce many ecological and pollutant problems in aquatic ecosystems. Some of those impacts are in relation with a water quality decrease, due to the use of toxic products as herbicides or pesticides, which induce changes in the ecological characteristics and processes.

In recent years, ecotoxicological studies have substantially increased in order to measure the ecological

* Corresponding author : E-mail : fguerre@ujaen.es effect of agricultural pollution on aquatic ecosystems (Van Dam et al. 1998). The use of acute toxicity data is essential to the ecotoxicological assessment of chemicals and has been recommended to improve the current toxicity database for different trophic groups in freshwater and saltwater ecosystems (Lenwood et al. 1998). The number and variety of freshwater species and bioassay procedures currently recommended in European Directives for assessing the risk posed by pollutants to freshwater ecosystems are rather limited (Pascoe et al. 2000). Algae, bacteria, and aquatic invertebrates are attractive organisms because their generation spans are shorter than those of higher organisms such as fish. The ecological relevance, and the advantages associated with the use of freshwater invertebrates for ecotoxicological tests have already been described (Snell et al. 1991, Snell \& Moffat 1992, Janssen et al. 1993). Rotifers and cladocerans are the most used organisms in toxicity tests, while copepods were used in a lower frequency (Calow 1998). Copper and dimethoate are both used regularly in the olive tree culture to control pest or nuisance organisms. Copper sulphate is normally used in olive tree cultivation in spring and autumn against Cycloconium oleaginum. Copper has two 
main oxidation states : $1^{+}$and $2^{+}$. The $\mathrm{Cu}^{2+}$ ion is the most environmentally relevant to aquatic systems and is generally considered the most toxic form to aquatic life (Lenwood et al. 1998). Exposure to high concentrations of copper can affect populations and individuals at morphological, physiological, biochemical or genetic levels (Troncoso et al. 2000). Dimethoate is an organophosphate insecticide, normally used in olive tree cultivation in spring against Bactrocera oleae. It is fairly soluble, stable in water, and its toxicity for aquatic organisms and birds has been reported as moderate to high (WHO 1989). Acute toxicity tests with dimethoate on non-target organisms have shown that several freshwater and marine species are sensitive, and especially crustaceans (WHO 1989, Sørensen et al. 1995, Bayley \& Baatrup 1996).

The literature related to the toxic effects of copper and dimethoate show that acute toxicity data were available for some freshwater and saltwater species, primarily benthos and fish, but reduced information is available on copepods (Calow 1998, Sorensen 1991). Given the past research with these two pesticides, the main hypothesis of this study was that copper and dimethoate may cause permanent reductions in the zooplankton communities in wetlands near olive tree plantations. Our goal was to determine the effect on survival and recruitment in the calanoid copepod Arctodiaptomus salinus (Daday), exposed to different copper and dimethoate concentrations.

\section{Material and methods}

A. salinus used in laboratory experiments were collected in Lagura Honda (UTM-geographic coordinates : 30SVG9961; 460 m.a.s.1.), an inland shallow ecosystem, situated in the Guadalquivir basin, southern Spain (Table 1). Copepods, the dominant fraction of zooplankton in this ecosystem (Castro 2004), were collected with a plankton net and brought into the laboratory immediately after collection. After one day of accommodation to laboratory conditions, females with egg sacs were gently separated from the rest of the sample. Part of this group was placed in a Petri dish to separate carefully the egg sac with fine needles. Egg sac carrying females and the isolated egg sacs were used in separate toxicity tests. The copepods were not fed during acclimation and subsequent exposure.

Toxicity experiments were carried out in periods in which the olive tree cultivation in Lagura Honda drainage basin was not treatment with pesticides or herbicides. Moreover, lake water was analysed and copper and dimethoate were not detectable. The female toxici-
Table 1. Limnological characteristics of Lagura Honda. Data from Castro (2004). (T.D.S. Total Dissolved Solids).

\begin{tabular}{ll}
\hline Area & $99433 \mathrm{~m}^{2}$ \\
Shoreline length & $1322.12 \mathrm{~m}$ \\
Shore development & 1.18 \\
Maximum depth & $3.16 \mathrm{~m}$ \\
Volume & $204726.39 \mathrm{~m}^{3}$ \\
Mean depth & $2.06 \mathrm{~m}$ \\
Chlorophyll-a & $0.07-1.57 \mu \mathrm{g} \mathrm{L}^{-1}$ \\
T.D.S. & $11.5-36.9$ \\
\hline
\end{tabular}

ty experiments consisted of static tests with a control and different copper and dimethoate concentrations (ranging from 0 to $4 \mathrm{mg} \mathrm{Cu} \mathrm{L}^{-1}$ and from 0 to $50 \mathrm{mg} \mathrm{di-}$ methoate $\mathrm{L}^{-1}$ ) that were added to previously filtered water from the lake. Three replicates at each concentration, with at least 15 females carrying egg sacs were placed in experimental glass vessels $(50 \mathrm{~mL})$. Controls consisted of glass vessels with females taken in the same collection and using the above mentioned lake water. The vessels were incubated at $20^{\circ} \mathrm{C}$. Copepod mortalities were recorded in each vessel at 24-h intervals and dead individuals were removed. The lethal concentration values affecting $50 \%$ of the population in 24-h, 48-h, 72-h and 96-h ( $\left.\mathrm{LC}_{50}\right)$ were determined from the linear regressions between the mortality probits and log-transformed values of dimethoate and copper concentrations. Values for $95 \%$ confidence limits were also calculated in all cases (Abel \& Axiak 1991). LC $_{50}$ values were considered to be significantly different $(\mathrm{p}<0.05)$ if the confidence intervals did not overlap (Roast et al. 1999).

Static tests with the egg sacs were conducted in conventional 24-well polystyrene multiwell plates. One control and three different copper concentrations $\left(0.5,1\right.$ and $\left.2 \mathrm{mg} \mathrm{Cu} \mathrm{L}^{-1}\right)$ and two dimethoate concentrations ( 2 and $20 \mathrm{mg}^{-1}$ dimethoate $\mathrm{L}^{-1}$ ) prepared as mentioned above, were used. Each well received one egg sac and three replicates were used at each concentration. The plates were also incubated at $20^{\circ} \mathrm{C}$. After 96-h, hatching rates and nauplii survival were registered (mean hatching time of A. salinus at $20^{\circ} \mathrm{C}$ is $82.4 \pm$ $0.4 \mathrm{~h}$; Jiménez-Melero, unpublished data). The effect of copper and dimethoate concentration on hatching rate and nauplius survival was tested and analysed by one way ANOVA (Sokal \& Rohlf 1995).

\section{Results}

Copepods mortality vs. copper/dimethoate concen- 
trations in adult female experiments of A. salinus during 24, 48, 72, and 96-h are shown in Figure 1. There was no mortality in control vessels during all tests. Total mortality occurred at $2 \mathrm{mg} \mathrm{Cu} \mathrm{L}^{-1}$ after 24-h and
$0.15 \mathrm{mg} \mathrm{Cu} \mathrm{L}^{-1}$ after $96-\mathrm{h}$ test. In dimethoate experiments, the values ranged between $40 \mathrm{mg}$ dimethoate $\mathrm{L}^{-1}$ after 24-h and $10 \mathrm{mg}$ dimethoate $\mathrm{L}^{-1}$ after 96-h test. The fitting parameters of the linear regressions of pro-
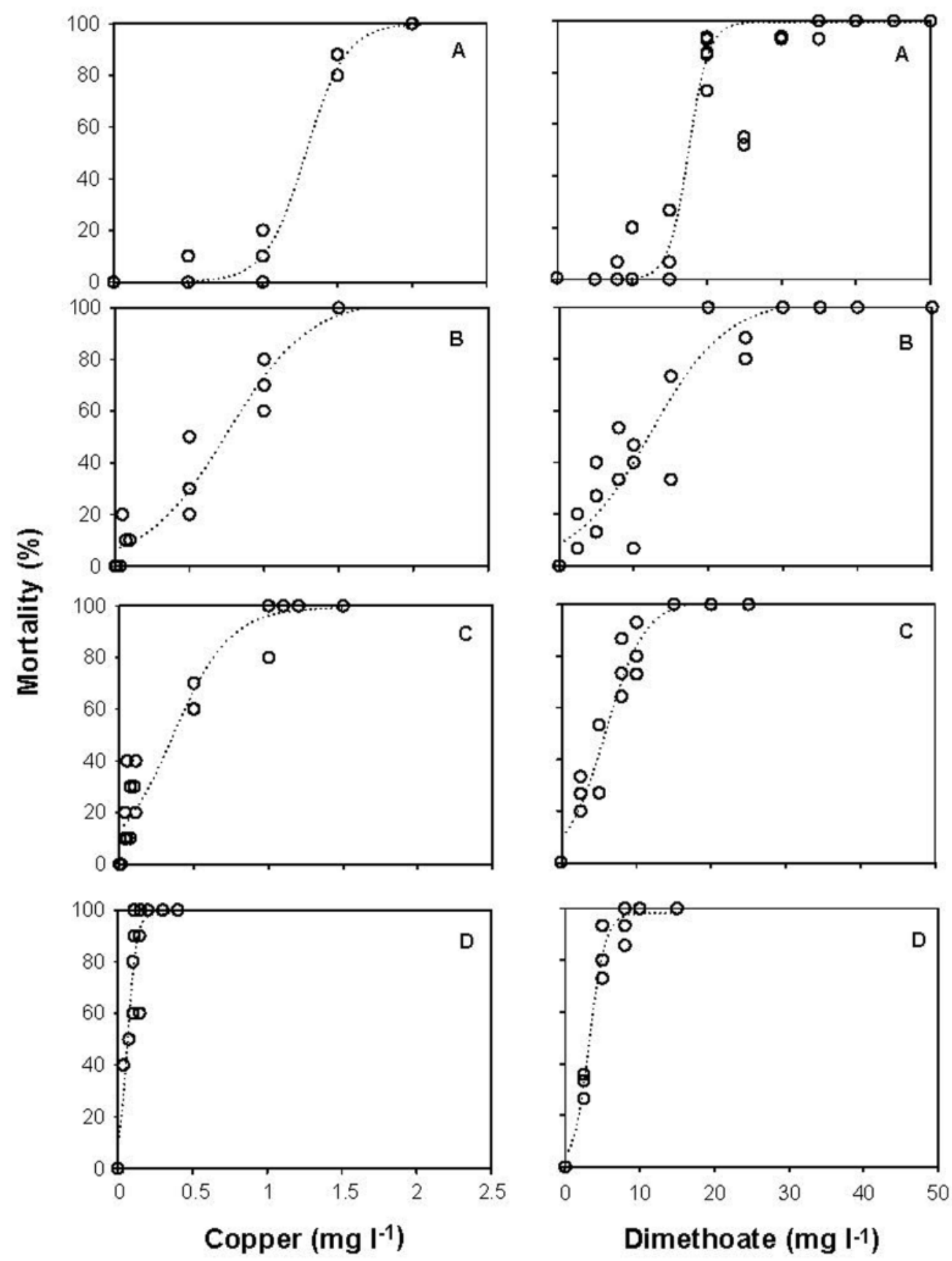

Fig. 1. Mortality in Arctodiaptomus salinus females after 24-h (A) ; 48-h (B) ; 72-h (C) and 96-h test (D) under different dimethoate and copper concentrations. 
Table 2. Summary of regression parameters obtained in the acute toxicity tests on Arctodiaptomus salinus females exposed to different dimethoate and copper concentrations and during different exposure times (Y, mortality expressed in probit ; X, logarithmic dimethoate or copper concentrations).

\begin{tabular}{cllccc}
\hline Time (h) & & Regression & $\mathrm{r}$ & $\mathrm{n}$ & $\mathrm{p}$ \\
\hline \multirow{2}{*}{24} & Copper & $\mathrm{y}=-1.02+5.00 \mathrm{x}$ & 0.61 & 13 & 0.001 \\
& Dimethoate & $\mathrm{y}=-10.10+4.99 \mathrm{x}$ & 0.77 & 12 & $<0.001$ \\
\multirow{2}{*}{48} & Copper & $\mathrm{y}=2.97+2.07 \mathrm{x}$ & 0.83 & 13 & $<0.001$ \\
& Dimethoate & $\mathrm{y}=1.77+1.15 \mathrm{x}$ & 0.70 & 13 & 0.001 \\
\multirow{2}{*}{72} & Copper & $\mathrm{y}=3.07+2.79 \mathrm{x}$ & 0.74 & 11 & $<0.001$ \\
& Dimethoate & $\mathrm{y}=1.94+1.28 \mathrm{x}$ & 0.73 & 17 & 0.001 \\
& Copper & $\mathrm{y}=3.14+3.70 \mathrm{x}$ & 0.83 & 7 & 0.001 \\
& Dimethoate & $\mathrm{y}=0.12+2.78 \mathrm{x}$ & 0.70 & 7 & 0.019 \\
\hline
\end{tabular}

bits vs. log-transformed copper/dimethoate concentrations are shown in Table 2. The mortality probit exhibited a positive correlation with the log-transformed copper/dimethoate concentrations and all regression lines showed high correlation values $(\mathrm{p} \leq 0.02)$. These regressions were used to estimate the $\mathrm{LC}_{50}$ and their 95\% confidence limits at each exposure time (Table 3 ).

Table $3 . \mathrm{LC}_{50}$ values and $95 \%$ confidence limits after 24, 48, 72 and 96-h test in Arctodiaptomus salinus females.

\begin{tabular}{ccccc}
\hline & \multicolumn{4}{c}{ Exposure time (h) } \\
$\mathrm{LC}_{50}$ & 24 & 48 & 72 & 96 \\
\hline Copper $\left(\mathrm{mg} \mathrm{L}^{-1}\right)$ & 1.06 & 0.62 & 0.25 & 0.06 \\
& $(0.82-1.37)$ & $(0.21-1.82)$ & $(0.11-0.58)$ & $(0.03-0.10)$ \\
Dimethoate $\left(\mathrm{mg} \mathrm{L}^{-1}\right)$ & 16 & 9.56 & 4.88 & 3.16 \\
& $(3.30-4.15)$ & $(4.08-7.14)$ & $(1.66-2.50)$ & $(0.84-1.16)$ \\
\hline
\end{tabular}

Hatching rates after 96-h of exposition time were significantly reduced in egg sacs exposed to $1 \mathrm{mg} \mathrm{Cu} \mathrm{L}^{-1}$

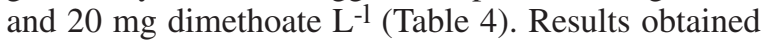
with copper concentrations showed that over these values there was no hatching process. No differences were found between hatching rates in control wells and in the wells with $0.5 \mathrm{mg} \mathrm{Cu} \mathrm{L}^{-1}$ and in $2 \mathrm{mg}^{\text {dimethoate } \mathrm{L}^{-1}}$ wells, respectively. So, these concentrations can be considered as no observed effect concentration (NOEC).

Table 4. Arctodiaptomus salinus eggs hatching rates and nauplius mortality observed at different dimethoate and copper concentrations after 96-h exposition.

\begin{tabular}{ccccc}
\hline Copper & \multicolumn{4}{c}{ Concentration $\left(\mathrm{mg} \mathrm{L}^{-1}\right)$} \\
& 0 & 0.5 & 1 & 2 \\
\hline Hatching rates (\%) & 100 & 100 & $50 \pm 40$ & 0 \\
Nauplius mortality (\%) & 0 & 0 & 100 & - \\
\hline & \multicolumn{4}{c}{ Concentration $\left(\mathrm{mg} \mathrm{L}^{-1}\right)$} \\
\hline Dimethoate & 0 & 2 & 20 \\
\hline Hatching rates (\%) & $98.3 \pm 9$ & $87.5 \pm 17.7$ & $33.5 \pm 13.4$ \\
Nauplius mortality (\%) & 0 & $21 \pm 5.6$ & 100 \\
\hline
\end{tabular}

After 96-h of exposure time, total nauplii mortality occurred when they were exposed to $1 \mathrm{mg} \mathrm{Cu} \mathrm{L}^{-1}$ and $20 \mathrm{mg}$ dimethoate $\mathrm{L}^{-1}$. No mortality occurred in control wells and in $0.5 \mathrm{mg} \mathrm{Cu} \mathrm{L}^{-1}$ wells, so, this last concentration can also be considered as NOEC.

\section{Discussion}

\section{Criticisms of the Method}

It has been hypothesised that a significant portion of applied and residual chemicals in most water bodies exists in unavailable forms (i.e., complexed, precipitated, and/or sorbed to particulate matter or dissolved organics). In closed laboratory systems, total concentration from initial application will remain constant, although the forms within the testing chambers may transform over time (Mastin \& Rodgers 2000). Therefore, experiments employing "clean" laboratory waters overestimate actual risks to non-target species (such as copepods), which live in aquatic systems where additional binding sites (i.e., ligands), may decrease acute toxicity (US EPA 1980, Gauss et al. 1985, US EPA 1992, Benson et al. 1994, Dobbs et al. 1994). Supporting more complex toxicity tests, Lenwood et al. (1998) indicate that microcosm and mesocosm data provide a more useful information for assessing the impact of a stressor on aquatic communities (e.g. aggregate responses of multiple species, observation of population and community recovery after exposure, and indirect effects resulting from changes in food supply). These kinds of experiences are worth carrying out to give a conclusion for the information related to the toxic effects on ecosystem production. However, European Directives for assessing the risk in aquatic toxicity projects recommended the validation process in which results of laboratory tests were compared with values obtained in the field, using structural and functional responses of communities. Pascoe et al. (2000) concluded that appropriately designed, relatively simple and inexpensive laboratory toxicity tests with a selection of test species are generally adequate, with small application factors, for predicting the environmental risk of polluting chemicals to freshwater ecosystems. Therefore, we believe that it is necessary to obtain a better database with this kind of "simple" experiment, increasing our knowledge to be able to manage the ecosystem in the future. Then we can obtain more information about how zooplankton composition and community structure can be altered as a result of its high susceptibility to a toxic. Additionally, we can also obtain information about the effects and 
consequences on higher trophic levels because zooplankton is on a principal pathway for the energy flow in the ecosystem (Álvarez-Cobelas \& Rojo 2000).

Toxicity effect on $A$. salinus : secondary production and risk assessment

The use of copper and dimethoate in olive tree agriculture in Andalusia is widely recognised (Guerrero 1991), but no information has been developed to know the effect of these pesticides on the aquatic biota in nearby watersheds. A review of the copper and dimethoate acute toxicity data on aquatic organisms is presented in Table 5. Our results indicate, when it is compared with the data presented in the table above mentioned, that $A$. salinus showed an intermediate resistance to copper (48-h $\left.\mathrm{LC}_{50} 0.62 \mathrm{mg} \mathrm{Cu} \mathrm{L}^{-1}\right)$, and is more resistant to dimethoate $\left(96-\mathrm{h} \mathrm{LC}_{50}\right.$ of $3.2 \mathrm{mg}$ dimethoate $\left.\mathrm{L}^{-1}\right)$, at least in experiments with a short exposure time.

Table 5. Review of the copper and dimethoate acute toxicity data on several aquatic organisms and different time of exposition.

\begin{tabular}{lccl}
\hline \multicolumn{1}{c}{ Organisms } & $\begin{array}{c}\text { Time } \\
\text { (hours) }\end{array}$ & $\begin{array}{c}\mathbf{L C ~ C}_{\mathbf{5 0}} \\
\left(\mathbf{m g ~ C u ~ L}^{-1}\right)\end{array}$ & \multicolumn{1}{c}{ Reference } \\
\hline Daphnia magna & 48 & 0.02 & Mastin \& Rodgers 2000 \\
Chironomus tentans & 48 & 1.14 & Mastin \& Rodgers 2000 \\
C. riparius & 48 & 1.17 & Dobbs et al. 1994 \\
Lecane hamaca & 48 & 0.23 & Pérez-Legaspi \& Rico 2001 \\
L. luna & 48 & 0.06 & Pérez-Legaspi \& Rico 2001 \\
L. quadridentata & 48 & 0.33 & Pérez-Legaspi \& Rico 2001 \\
\hline \multicolumn{1}{c}{ Organisms } & Time & LC C $_{50}$ & \multicolumn{1}{c}{ Reference } \\
& (hours) & (mg Dimethoate L L & \\
\hline Daphnia magna & 504 & 0.032 & Sloof \& Canton 1983 \\
Gammarus lacustris & 96 & 0.2 & Sanders 1969 \\
Neomysis integer & 96 & 0.4 & Roast et al. 1969 \\
\hline
\end{tabular}

The negative effect of copper and dimethoate on this planktonic crustacean is not only over the adults, but also acts on species recruitment, as this study has demonstrated with the reduction in hatching rates and in nauplius survival. The effect of the cupric ion activity on survival and development in other adult and nauplii copepods has been also described in the marine species Acartia tonsa (Dana) by Sunda et al. (1987). Moreover, a negative copper effect in grazing activity has also been reported in other calanoid copepods (Sharp \& Stearns 1997), and consequently in egg production (Kiørboe et al. 1985). The negative effects of dimethoate over other crustacean have been also described (Roast et al. 1999). Sloof \& Canton (1983) founded that a concentration of $0.1 \mathrm{mg}$ dimethoate $\mathrm{L}^{-1}$ affect reproduction in D. magna. Thus, information about the effects of the non-acute tests is crucial in freshwater copepods in order to understand how the physiology and bionenergetics of this zooplanktonic group can be affected.

Based on $\mathrm{LC}_{50}$ values from the present study, copper and dimethoate are toxic susbtances to A. salinus. This species is one of the most important components in Laguna Honda trophic web (Castro 2004), and consequently, any negative effect on its population also has an effect on the whole aquatic community, and on several ecological processes, such as secondary production. This is a significant aspect that is normally removed from traditionally toxicology studies. In this sense, if the estimation of secondary production in copepods is based essentially on female biomass and on hatching rates (Poulet et al. 1995), then special attention must be paid to the negative effects over those parameters. So, adult female mortality, nauplius stage mortality and in addition the reduction in hatching rates induced by copper and dimethoate involves a decrease in secondary production estimation.

Moreover, Laguna Honda is a shallow, saline lake whose seasonal behaviour is strongly dependent on the annual hydrological budget, and in addition limnological and ecological characteristics have a large interannual variability (Castro 2004). This implies that changes in physicochemical conditions associated to this interannual variability could be responsible for the different bioavailability of chemical products; for example, the toxicity generally decreases when water hardness increases (Chapman et al. 1980). Then, the results showed in this study must be considered over the environmental and experimental conditions that have been obtained.

\section{Conclusion}

Andalusia is a region situated in the south of Spain that has been historically transformed by intensive agricultural activity. In this area there are many wetlands completely surrounded by intensive agriculture (Ortega et al. 2003). The olive tree is the main cultivated species, representing in this area a monoculture in continuous growth. The culture techniques are highly aggressive over aquatic natural ecosystems, mainly due to ploughing and the increase in the use of herbicides and pesticides (Guerrero et al. 2005), but these are not the only chemicals used, and so the synergy situation must be considered. This variety of questions (e.g. laboratory/field tests, single/multiple species, toxicant interactions, etc.) must be taken into account before initiating and designing any management plan or process that improves the ecological situation in this kind of ecosystems affected in a great manner by intensive agricultural procedures. Finally, the results ob- 
tained in this study of $24-\mathrm{h} \mathrm{LC}_{50}$ are lower than the regular dose used in agricultural procedures (1875-3750 mg Cu L-1 and 400-600 mg dimethoate $\mathrm{L}^{-1}$; De Liñán 1997). Consequently, special attention has to be paid to the regulation of the use of pesticides in aquatic systems that are subjected to traditional agricultural techniques.

\section{Acknowledgements}

Thanks to Consejería de Medio Ambiente (Junta de Andalucía) for the permission for sampling in Laguna Honda. We acknowledge two anonymous referees for helpful comments. This work was supported by the Comisión Interministerial de Ciencia y Tecnología, Spain (CICYT Project PB98-0307).

\section{References}

Abel P.D. \& Axiak V. 1991. - Ecotoxicology and the marine environment. Ellis Horwood, New York, 269pp.

Álvarez-Cobelas M. \& Rojo, C. 2000. - Ecological goal functions and plankton communities in lakes. J. Plankton Res., 22, 729-748.

Bayley M. \& Baatrup E. 1996. - Pesticide uptake and locomotor behaviour in the woodlouse : an experimental study employing video tracking and ${ }^{14} \mathrm{C}$ labelling. Ecotoxicology, 5, 35-45.

Benson W.H., Alberts J.J., Allen H.E., Hunt C.D. \& Newman M.C. 1994. - Synopsis of discussion session on the bioavailability of inorganic contaminants. Pages 63-71 in Bioavailability, physical, chemical, and biological interactions. Hamelink J.L., Landrum P.F., Bergman H.L. \& Ben-son W.H. (eds.). Lewis, Ann Arbor, Miami.

Bernáldez F.G. 1987. - Las zonas encharcables españolas: El marco conceptual. Pages 9-30 in Bases científicas para la protección de los humedales en España. Real Academia de Ciencias Exactas, Físicas y Naturales (ed.). Real Academia de Ciencias Exactas, Físicas y Naturales, Madrid.

Calow P. 1998. - Handbook of ecotoxicology. Blackwell Scientific Publications, London, 885pp.

Casado S. \& Montes C. 1995. - Guía de los lagos y humedales de España. J.M. Reyero, Madrid, 255pp.

Castro M.C. 2004. - Caracterización limnológica y variabilidad temporal de la comunidad planctónica en Laguna Honda (Jaén). Tesis Doctoral. Universidad de Jaén, Jaén, 164pp.

Chapman G.A., Ota S. \& Recht F. 1980. - Effects of water hardness on the toxicity of metals to Daphnia magna. Pages 1-17 in Aquatic Toxicity Information Retrieval database. U.S. Environmental Protection Agency (ed.). Washington DC.

De Liñán C. 1997. - Farmacología vegetal. Ediciones Agrotécnicas, Madrid, 1196pp.

Dobbs M.G., Farris J.L., Reash D., Cherry S. \& Cairns, J. 1994. Evaluation of the resident-species procedure for developing sitespecific water quality criteria for copper in Blaine Creek, Kentucky. Environ. Toxicol. Chem., 13, 963-971.

Gauss J.D., Woods P.E., Winner R.W. \& Skillings J.H. 1985. - Acute toxicity of copper to three life stages of Chironomus tentans as affected by water hardness-alkalinity. Environ. Pollut., 37, 149 157.

Guerrero A. 1991. - Nueva olivicultura. Mundiprensa, Madrid, 271pp.

Guerrero F., Parra G., Jiménez-Gómez F., Castro M.C., JiménezMelero R., Galotti A. \& Ortega F. 2005. - Los ecosistemas acu.ticos en el contexto de los agrosistemas : la comarca del Alto Gua- dalquivir. Pages 383-404 in La cultura del olivo. Ecología, economía, sociedad. Anta J.L., Palacios J. \& Guerrero F. (eds.). Universidad de Jaén, Jaén.

Janssen C.R., Ferrando Rodrigo M.D. \& Persoone G. 1993. - Ecotoxicological studies with the freshwater rotifer Brachionus calyciflorus. I. Conceptual framework and applications. Hydrobiologia, 255/256, 21-32.

Kiørboe T., Møhlenberg F. \& Hamburger K. 1985. - Bioenergetics of the planktonic copepod Acartia tonsa ; relation between feeding, egg production respiration and composition of specific dynamic action. Mar. Ecol. Prog. Series, 26, 85-97.

Lenwood W.H.Jr., Scott M.C. \& Killen W.D. 1998. - Ecological risk assessment of copper and cadmium in surface waters of Chesapeake Bay watershed. Environ. Toxicol. Chem., 17, 1172-1189.

Mastin B.J. \& Rogers Jr.J.H. 2000. - Toxicity and bioavailability of copper herbicides (clearigate, cutrine-plus, and copper sulfate) to freshwater animals. Arch. Environ. Contam. Toxicol., 39, 445451

Ortega F., Parra G. \& Guerrero F. 2003. - Los humedales del Alto Guadalquivir : inventario, tipologías y estado de conservación. Pages 113-123 in Ecología, manejo y conservación de los humedales. Paracuellos M. (ed.). Instituto de Estudios Almerienses, Almería.

Pascoe D., Wenzel M.A., Janssen C., Girling A.E., Juèttner I., Fliedner A., Blockwell S.J., Maund S. J., Taylor E. J., Diedrich M. Persoone G., Verhelst P.R., Stephenson N.O., Crossland G.C., Mitchell N., Pearson L., Tattersfield J.P., Lay A., Peither R., Neumeier B. \& Velletti A.R. 2000. - The development of toxicity tests for freshwater pollutants and their validation in stream and pond mesocosms. Wat. Res., 34, 2323-2329.

Pérez-Legaspi I.A. \& Rico-Martínez R. 2001. - Acute toxicity tests on three species of the genus Lecane (Rotifera : Monogononta). Hydrobiologia, 446/447, 375-381.

Poulet S., Ianora A., Laabir M. \& Breteler W.C.M. 1995. - Towards the measurement of secondary production and recruitment in copepods. ICES J. Mar. Sci., 52, 359-368.

Roast S.D., Thompson R.S., Donkin P., Widdows J. \& Jones M.B. 1999. - Toxicity of the organophosphate pesticides chlorpyrifos and dimethoate to Neomysis integer (Crustacea : Mysidacea). Wat. Res., 33, 319-326.

Sanders H.O. 1969. - Toxicity of pesticides to the crustacean Gammarus lacustris. Technical Paper, 25, U.S. Fish and Wildlife Service (ed.), 18pp.

Sharp A.A. \& Stearns D.E. 1997. - Sublethal effect of cupric Ion Activity on the grazing behaviour of three calanoid copepods. Mar. Pollution Bulletin, 34, 1041-1048.

Sloof W. \& Canton J.H. 1983. - Comparison of the susceptibility of 11 freshwater species to 8 chemical compounds. II. (Semi) chronic toxicity test. Aquat. Toxicol., 4, 271-282.

Snell T.W. \& Moffat B. 1992. - A two-day life cycle test with Brachionus calyciflorus. Environ. Toxicol. Chem., 11, 1249-1257.

Snell T.W., Moffat B., Janssen C.R. \& Persoone G. 1991. - Acute toxicity bioassays using rotifer. IV. Effects of cyst age, temperature and salinity on the sensitivity of Brachionus calyciflorus. Ecotoxicol. Environ. Saf., 21, 308-317.

Sokal R.R. \& Rohlf J. 1995. - Biometry. W.H. Freeman and Company, New York, 887pp.

Sørensen E. M. B. 1991. - Metal poisoning in fish. Pages 61-64 in Ambient aquatic life criteria for copper. U.S. Environmental Protection Agency, Washington, DC.

Sørensen F. F., Bayley M. \& Baatrup E. 1995. - The effects of sublethal dimethoate exposure on the locomotor behavior of the collembolan Folsomia candida (Isotomidae). Environ. Toxicol. Chem., 14, 1587-1590. 
Sunda W.G., Tester P.A. \& Huntsman S.A. 1987. - Effect of cupric and zinc ion activities on the survival and reproduction of marine copepods. Mar. Biol., 94, 203-210.

Troncoso L., Galleguillos R. \& Larrain A. 2000. - Effects of copper on the fitness of the Chilean scallop Argopecten purpuratus (Mollusca : Bivalvia). Hydrobiologia, 420, 185-189.

US Environmental Protection Agency 1980. - Ambient water quality criteria for copper. U.S. Environmental Protection Agency, Washington DC., 207pp.

US Environmental Protection Agency 1992. - Interim guidance on interpretation and implementation of aquatic life criteria for metals. U.S. Environmental Protection Agency, Washington DC., 24pp.

Van Dam R.A., Camilleri C. \& Finlayson C.M. 1998. - The potential of rapid assessment techniques as early warning indicators of wetland degradation : a review. Environ. Toxicol. Water Qual., 13, 297-312.

WHO. 1989. - Environmental health criteria 90 : Dimethoate. World Health Organization, Geneva, 85pp. 